\title{
Meier-Gorlin syndrome presenting as early infantile epileptic encephalopathy
}

\author{
Adil Ahmed Khan, ${ }^{1}$ Chaithanya Reddy, ${ }^{1}$ Arushi Gahlot Saini, ${ }^{1}$ Sameer Vyas ${ }^{2}$
}

'Pediatrics, Post Graduate Institute of Medical Education and Research, Chandigarh, India ${ }^{2}$ Radiodiagnosis, Post Graduate Institute of Medical Education and Research, Chandigarh, India

\section{Correspondence to Dr Arushi Gahlot Saini; doc.arushi@gmail.com}

Accepted 1 July 2020

Check for updates

(C) BMJ Publishing Group Limited 2020. No commercial re-use. See rights and permissions. Published by BMJ.

To cite: Khan AA, Reddy C, Saini $A G$, et al. BMJ Case Rep 2020;13:e235468. doi:10.1136/bcr-2020235468

\section{DESCRIPTION}

A 6-month-old female infant presented with recurrent seizures, delayed development and feeding problems since 3 months of age. The onset of seizures occurred after an episode of high-grade fever with routine vaccination at 3 months of age. She developed generalised-onset tonic, focal-onset clonic and multifocal myoclonic jerks over the subsequent months. The development had become stagnant after the onset of recurrent seizures resulting in epileptic encephalopathy. She was born to non-consanguineously married parents by a term, vaginal, uneventful delivery. The birth weight was $2 \mathrm{~kg}$. Mother had a history of two abortions in the second trimester and was detected to have subclinical hypothyroidism during this pregnancy. On examination, she had a head circumference of $34 \mathrm{~cm}$ ( $-6 \mathrm{z}$ scores) with sutural overriding, length $62 \mathrm{~cm}(-1.8 \mathrm{z}$ scores $)$ and weight $5.6 \mathrm{~kg}(-2 \mathrm{z}$ scores). There was facial dysmorphism, protruding tongue, short philtrum, telecanthus, short and broad nasal bridge, retrognathia, high arched palate, inverted V-shaped upper lip, clinodactyly of the fifth finger, generalised hypotonia, brisk deep tendon reflexes and normal fundi bilaterally. The rest of the systemic examination was unremarkable. A clinical diagnosis of early, infantile-onset, epileptic encephalopathy secondary to a structural, metabolic or genetic aetiology was considered. Investigations showed a normal haemogram, renal, liver and thyroid function tests. Urinary sulfites were not detected. Serum ammonia was 112 $\mu \mathrm{mol} / \mathrm{L}(<80 \mu \mathrm{mol} / \mathrm{L})$, arterial lactate $2.5 \mathrm{mmol} / \mathrm{L}$ (0.8-1.2 mmol/L), plasma homocysteine 2.74 $\mu \mathrm{mol} / \mathrm{L}(4-15 \mu \mathrm{mol} / \mathrm{L})$ and serum biotinidase 8 $\mathrm{mIU} / \mathrm{mL}$ (5-9 mIU/mL). Cerebrospinal fluid examination, glycine, amino acid and carnitine profiles on tandem mass spectroscopy and urinary gas chromatography were normal. The visual evoked potential was normal. MRI of the brain showed diffuse atrophy and white-matter signal changes (figure 1A-D). The electroencephalogram showed asynchronous interictal discharges with intermittent generalised burst and burst attenuation pattern with multifocal spikes (figure 2). Genetic analysis showed a homozygous missense variant in exon 9 of the CDT1 gene (chr16:88873770C $>$ T) that results in the amino acid substitution of tryptophan for arginine at codon 453 (p.Arg453Trp; ENST00000301019.4). In silico prediction was damaging by PolyPhen-2 (HumDiv), Sorting Intolerant From Tolerant (SIFT), likelihood ratio test (LRT) and MutationTaster2. A final diagnosis of Meier-Gorlin syndrome (MGS) was considered.

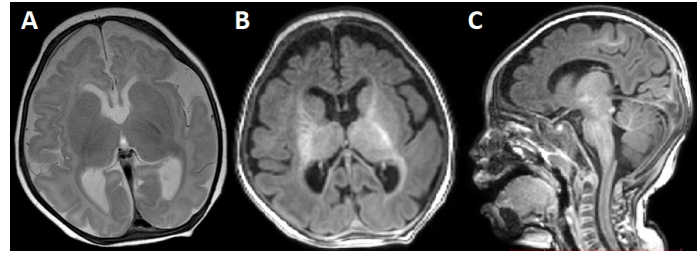

Figure $1(\mathrm{~A}-\mathrm{C}) \mathrm{MRI}$ of the brain at 6 months of age showing diffuse cerebral atrophy, symmetrical white matter changes in bilateral cerebral hemispheres (predominantly in the subcortical white matter), opening up of bilateral Sylvian fissures, atrophic corpus callosum and bilateral hippocampi and normal myelination for age.

She was started on antiepileptic drugs, and gradually the seizure diminished in frequency. However, the baby expired at 7 months of age due to intercurrent seizures.

MGS is a rare, an autosomal recessive, primordial dwarfism syndrome characterised by the triad of microtia, absent or hypoplastic patellae and short stature due to variations in the genes primarily involved in origin licensing (crucial step for DNA replication) namely ORC1, ORC4, ORC6, CDT1, CDC6, MCM5, GMNN and DONSON. ${ }^{1}$ Fetal growth is often delayed, resulting in intrauterine growth retardation (97\%) and in three reported cases, termination was done due to the presence of severe retardation and congenital anomalies. ${ }^{2}$ The same phenomenon may explain the previous pregnancy losses and low birth weight in the index case. Also, a 'lethal' homozygous or compound heterozygous loss of function variant in the earlier pregnancies of the mother may have causes recurrent abortions. Nearly one-fifth of the patients may show only two out of three cardinal features, and one patient has

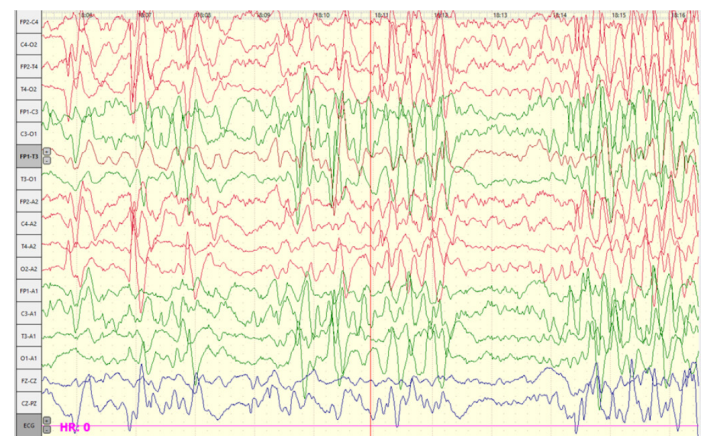

Figure 2 Electroencephalography image consisting of an epoch of $12 \mathrm{~s}$ showing bursts of generalised spike-wave discharges, followed by attenuation of the background (sensitivity $7 \mu \mathrm{V} / \mathrm{mm}$, HPF $70 \mathrm{~Hz}$, LPF $1 \mathrm{~Hz}$ ) suggestive of epileptic encephalopathy. 
been described with short stature. More phenotypic variations are expected as the number of reported cases of this rare syndrome increases. Several of the features may not be appreciated in early months of infancy. The index case was not evaluated for patellar changes and there was no microtia. Other features associated with the syndrome such as feeding problems, moderate to severe microcephaly, delayed development and abnormal facial phenotype with retrognathia, high arched palate and clinodactyly of the fifth finger were noted in the index patient. However, several of the facial features become prominent with age. The genetic variation in the index case has previously been described in a compound heterozygous state in a female with microcephaly and normal stature. ${ }^{3}$ However, a review of the literature did not find any association between MGS and seizures. Similarly, defects in CDT1 protein

\section{Learning points}

- Meier-Gorlin syndrome is a rare, an autosomal recessive, primordial dwarfism syndrome characterised by the triad of microtia, absent or hypoplastic patellae and short stature (growth retardation).

- Early infantile epileptic encephalopathy may be rarely associated.

- Early recognition by genetic testing helps in prognosticating the parents as well as helps in prenatal counselling for subsequent pregnancies. have been associated with various ectodermal anomalies, including the bony skeleton, cartilaginous structures and skin. ${ }^{23}$ Its overexpression has been identified in cells of various malignancies. But epilepsy secondary to CDT1 variants is not known till now. After the exclusion of variants involving common genes associated with severe epileptic encephalopathy following a brief febrile seizure, namely SCN1A, SCN2A, PCDH19 and SCN8A in genetic analysis, we conclude that epileptic encephalopathy may be the unrecognised component of the phenotypic spectrum of this syndrome.

Contributors AAK: patient management, literature review and initial draft manuscript preparation. CR: patient management, literature review and final approval of the version to be published. AGS: patient management, critical review of the manuscript and final approval of the version to be published. SV: interpretation of radiological data, critical review of the manuscript and final approval of the version to be published.

Funding The authors have not declared a specific grant for this research from any funding agency in the public, commercial or not-for-profit sectors.

Competing interests None declared.

Patient consent for publication Parental/guardian consent obtained.

Provenance and peer review Not commissioned; externally peer reviewed.

\section{REFERENCES}

1 Knapp KM, Sullivan R, Murray J, et al. Linked-read genome sequencing identifies biallelic pathogenic variants in DONSON as a novel cause of Meier-Gorlin syndrome. J Med Genet 2020;57:195-202.

2 Guernsey DL, Matsuoka M, Jiang H, et al. Mutations in origin recognition complex gene ORC4 cause Meier-Gorlin syndrome. Nat Genet 2011;43:360-4.

3 Bicknell LS, Bongers EMHF, Leitch A, et al. Mutations in the pre-replication complex cause Meier-Gorlin syndrome. Nat Genet 2011;43:356-9.

Copyright 2020 BMJ Publishing Group. All rights reserved. For permission to reuse any of this content visit

https://www.bmj.com/company/products-services/rights-and-licensing/permissions/

BMJ Case Report Fellows may re-use this article for personal use and teaching without any further permission.

Become a Fellow of BMJ Case Reports today and you can:

- Submit as many cases as you like

- Enjoy fast sympathetic peer review and rapid publication of accepted articles

- Access all the published articles

- Re-use any of the published material for personal use and teaching without further permission

Customer Service

If you have any further queries about your subscription, please contact our customer services team on +44 (0) 2071111105 or via email at support@bmj.com.

Visit casereports.bmj.com for more articles like this and to become a Fellow 